\title{
Isolation and characterization of dihydropteridine reductase from human liver
}

\author{
Frank A. FIRGAIRA, ${ }^{*}$ Richard G. H. COTTON* and David M. DANKS*† \\ *Genetics Research Unit, Royal Children's Hospital Research Foundation, Parkville, Vic. 3052, and \\ + Department of Paediatrics, University of Melbourne, Parkville, Vic. 3052, A ustralia
}

(Received 20 October 1980/Accepted 27 February 1981)

\begin{abstract}
Dihydropteridine reductase (EC 1.6.99.7) was purified from human liver obtained at autopsy by a three-step chromatographic procedure with the use of (1) a naphthoquinone affinity adsorbent, (2) DEAE-Sephadex and (3) CM-Sephadex. The enzyme was typically purified 1000 -fold with a yield of $25 \%$. It gave a single band on non-denaturing and sodium dodecyl sulphate/polyacrylamide-gel electrophoresis, and showed one spot on two-dimensional gel electrophoresis. The molecular weight of the enzyme was determined to be 50000 by sedimentation-equilibrium analysis and 47500 by gel filtration. On sodium dodecyl sulphate/polyacrylamide-gel electrophoresis, a single subunit with mol.wt. 26000 was observed. A complex of dihydropteridine reductase with NADH was observed on gel electrophoresis. The isoelectric point of the enzyme was estimated to be $\mathrm{pH}$ 7.0. Amino acid analysis showed a residue composition similar to that seen for the sheep and bovine liver enzymes. The enzyme showed anomalous migration in polyacrylamide-gel electrophoresis. A Ferguson plot indicated that this behaviour is due to a low net charge/size ratio of the enzyme under the electrophoretic conditions used. The kinetic properties of the enzyme with tetrahydrobiopterin, 2-amino-4-hydroxy-6,7-dimethyl-5,6,7,8-tetrahydropteridine, NADH and NADPH are compared, and the effects of $\mathrm{pH}$, temperature and a number of different compounds on catalytic activity are presented.
\end{abstract}

Dihydropteridine reductase (NADH:quinonoid 6,7-dihydropteridine oxidoreductase, EC 1.6.99.7) is an essential enzyme component of the complex systems catalysing the hydroxylation of phenylalanine, tyrosine and tryptophan (Kaufman \& Fisher, 1974).

As shown in Scheme 1, hydroxylation of these amino acids is coupled to the oxidation of tetrahydrobiopterin (pterin cofactor) to quinonoid di- hydrobiopterin, and is catalysed by the respective amino acid hydroxylase enzyme. A second enzyme, dihydropteridine reductase, is common to the three systems and is required for the reduction of the unstable quinonoid pterin to the active tetrahydro form through the oxidation of NADH. This recycling of the cofactor allows tetrahydrobiopterin to function catalytically in these reactions.

Dihydropteridine reductase has been isolated and

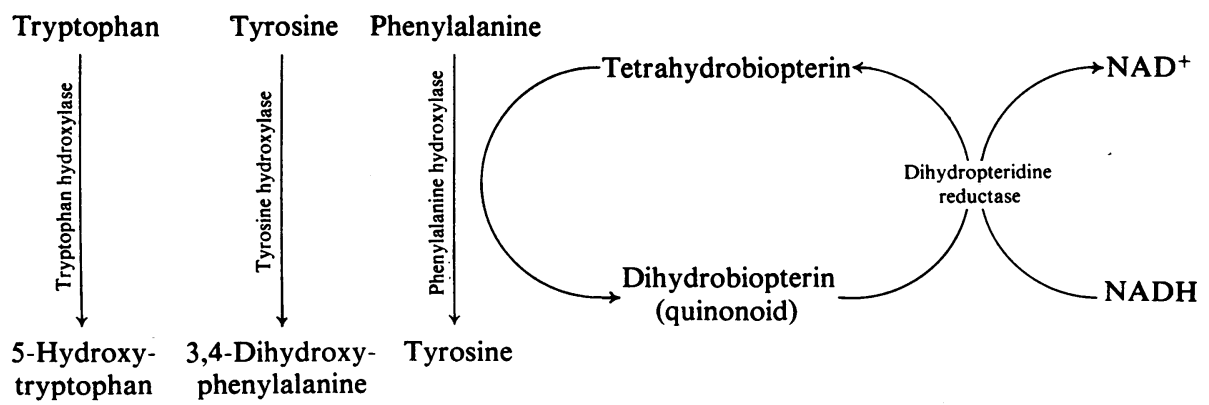

Scheme 1. Involvement of dihydropteridine reductase in the hydroxylation of the aromatic amino acids 
characterized from sheep liver (Craine et al., 1972; Cheema et al., 1973; Webber et al., 1978) and brain (Cheema et al., 1973), bovine liver (Hasegawa, 1977; Aksnes et al., 1979), adrenal medulla (Cheema et al., 1973; Aksnes et al., 1979), kidney (Chauvin et al., 1979) and brain (Snady \& Musacchio, 1978), rat liver (Webber et al., 1978) and a Pseudomonas species (Williams et al., 1976). In the main, these studies have indicated a similarity of properties and structure for dihydropteridine reductase from all these sources. These enzymes were shown to have molecular weights ranging from 42000 to 52000 , composed of two subunits of half that weight.

The functional significance of dihydropteridine reductase has been demonstrated by the description of children with malignant hyperphenylalaninaemia due to an inherited deficiency of this enzyme (for review see Danks et al., 1978). A molecular understanding of this disorder depends on the analysis of the structure of normal and mutant human enzyme.

Until recently, however, little was known about the structure of human dihydropteridine reductase. Craine et al. (1972) reported some kinetic properties of a 25-fold-purified enzyme from human liver. Later Cotton \& Jennings (1978) described an affinity adsorbent for this enzyme and purified it 400-fold from human liver; the preparation was shown to be approx. $50 \%$ pure and they reported a molecular weight of 100000 for the native enzyme. This finding was of interest, as it indicated that perhaps a major difference existed between human dihydropteridine reductase and other mammalian dihydropteridine reductases previously examined.

In the present paper we describe an efficient procedure for the purification to homogeneity of dihydropteridine reductase from normal human liver. Studies of the enzyme's native and subunit molecular weight were performed, and these and other physicochemical characteristics of the enzyme are presented.

\section{Materials and methods}

\section{Tissue obtained at autopsy}

Human livers were obtained 4-24h post mortem from children suffering from various causes. The tissue was used immediately or stored at $-20^{\circ} \mathrm{C}$. During the development of the purification procedure, six different livers were used.

\section{Chemicals}

All chemicals used were of analytical grade where possible. NADH, NADPH, NAD ${ }^{+}$and dithiothreitol were from Calbiochem (San Diego, CA, U.S.A.); 2-amino-4-hydroxy-6,7-dimethyl-5,6,7,8tetrahydropteridine hydrochloride and 5,5'-dithio- bis-(2-nitrobenzoic acid) were from Aldrich (Milwaukee, WI, U.S.A.). Tetrahydrobiopterin was generously supplied by Dr. W. L. F. Armarego (Australian National University, Canberra, A.C.T., Australia). AH-Sepharose, DEAE-Sephadex A-50, CM-Sephadex C-50 and Sephadex G-100 were from Pharmacia Fine Chemicals (Uppsala, Sweden); proteins used to calibrate the column in gel filtration were purchased from Sigma Chemical Co. (St. Louis, MO, U.S.A.); chymotrypsinogen was from Worthington Biochemical Corp. (Freehold, NJ, U.S.A.). Sodium dodecyl sylphate and ammonium persulphate were purchased from BDH Chemicals (Poole, Dorset, U.K.); acrylamide, $N N^{\prime}$-methylenebisacrylamide and 2-mercaptoethanol were from Merck (Darmstadt, Germany); $N N N^{\prime} N^{\prime}$-tetramethylethylenediamine and dimethyl suberimidate were obtained from Sigma. $N$-Ethylmaleimide and p-chloromercuribenzoic acid were from Nutritional Biochemical Corp. (Cleveland, OH, U.S.A.); iodoacetamide, $\mathrm{HgCl}_{2}, \mathrm{MgCl}_{2}, \mathrm{CoCl}_{2}, 2,2^{\prime}$-bipyridyl and EDTA were from $\mathrm{BDH} ; \mathrm{MnCl}_{2}$ was from Sigma; butane-2,3-dione monoxime was from Eastman Organic Chemicals (Rochester, NY, U.S.A.); $o$-phenanthroline was from Hopkin and Williams (Chadwell Heath, Essex, U.K.).

\section{Dihydropteridine reductase assay}

Dihydropteridine reductase activity (pterindependent oxidation of NADH) was recorded on a Varian 625 double-beam spectrophotometer, as the rate of change in absorbance at $340 \mathrm{~nm}$ with the synthetic cofactor 2-amino-4-hydroxy-6,7dimethyl-5,6,7,8-tetrahydropteridine hydrochloride $(80 \mu \mathrm{M})$ and $\mathrm{NADH}(100 \mu \mathrm{M})$ as substrates at $37^{\circ} \mathrm{C}$ (Firgaira et al., 1979). A molar absorption coefficient of $6220 \mathrm{M}^{-1} \cdot \mathrm{cm}^{-1}$ for NADH at $340 \mathrm{~nm}$ was used in calculating enzymic activity (Horecker \& Kornberg, 1948). One unit of enzyme activity represents $1 \mu \mathrm{mol}$ of NADH oxidized $/ \mathrm{min}$, and specific activity is in units $/ \mathrm{mg}$ of protein. Protein was determined by the method of Lowry et al. (1951), with bovine albumin stock solution 905-10 (Sigma) as standard.

Kinetic experiments were conducted essentially as described previously (Firgaira et al., 1979). Michaelis constants and maximal velocities were obtained from linear-regression analysis of Lineweaver-Burk double-reciprocal plots (Lineweaver \& Burk, 1934).

To study the effect of various compounds, enzyme and reagent of interest were incubated for $5 \mathrm{~min}$ at $37^{\circ} \mathrm{C}$ in the assay mixture (without NADH or pterin). After incubation, enzyme activity was determined as usual by addition of NADH and pterin. The ability of NADH to protect the enzyme against inactivation was assessed by preincubating the enzyme in the assay mixture (without pterin); 
then after 5 min the reagent of interest was added to the mixture, which was incubated for a further $5 \mathrm{~min}$ before determination of activity by addition of pterin substrate to the mixture.

\section{Isolation of human liver dihydropteridine reductase}

All procedures were performed at $4^{\circ} \mathrm{C}$ unless otherwise specified.

Extraction. Liver tissue (approx. $300 \mathrm{~g}$ ) was cut into small pieces with a scalpel and homogenized in $0.1 \mathrm{M}$-Tris/ $\mathrm{HCl}$ buffer, $\mathrm{pH} 8.6$, containing $0.1 \mathrm{~mm}$ EDTA $(2 \mathrm{ml} / \mathrm{g}$ wet wt. of tissue) in an electric blender. The homogenate was centrifuged (at $30000 \mathrm{~g}$ for $45 \mathrm{~min}$ ), and the supernatant was filtered through cotton gauze to remove lipid material. The sedimented liver tissue was re-extracted in half the volume of the same buffer, and the two supernatants were pooled.

Affinity chromatography. The liver extract was adjusted to $0.8 \mathrm{M}-\mathrm{NaCl}$ and $0.1 \mathrm{mM}-\mathrm{NADH}$, fine particulate material remaining in solution was removed by passage through a pre-column of Sepharose 4B-CL $(6 \mathrm{~cm} \times 3 \mathrm{~cm}$, equilibrated in extraction buffer), and the eluate was applied directly to a column $(4 \mathrm{~cm} \times 4 \mathrm{~cm})$ of 1,2-naphthoquinoneAH-Sepharose (Cotton \& Jennings, 1978).

After passage of the extract, the column was washed successively with (1) $400 \mathrm{ml}$ of buffer 1 $(0.8 \mathrm{M}-\mathrm{NaCl} / 50 \mathrm{~mm}$-Tris/HCl buffer, $\mathrm{pH} 7.6)$ containing $0.1 \mathrm{mM}-\mathrm{NADH}$, (2) $300 \mathrm{ml}$ of buffer $2(0.8 \mathrm{M}$ $\mathrm{NaCl} / 0.1 \mathrm{M}-\mathrm{Na}_{2} \mathrm{CO}_{3} / \mathrm{NaHCO}_{3}$ buffer, $\mathrm{pH} 10.9$ ) containing $0.1 \mathrm{mM}-\mathrm{NADH}$ and (3) $300 \mathrm{ml}$ of buffer 2 without NADH. The bound reductase was then eluted with $50 \mathrm{ml}$ of buffer 1 followed by $300 \mathrm{ml}$ of the same buffer containing $2 \mathrm{~mm}$-dithiothreitol (see Fig. 1). Fractions eluted at $\mathrm{pH} 10.9$ were adjusted immediately to $\mathrm{pH} 7.6$ with $\mathrm{HCl}$. The flow rate used was $3-4 \mathrm{ml} / \mathrm{min}$ throughout. Fractions containing dihydropteridine reductase activity were pooled and dialysed exhaustively against $50 \mathrm{~mm}$ Tris/ $\mathrm{HCl}$ buffer, $\mathrm{pH} 7.8$.

The adsorbent was regenerated with dithiothreitol as a routine after each column run (Cotton \& Jennings, 1978).

DEAE-Sephadex chromatography. The dialysed enzyme preparation was applied to a column $(2 \mathrm{~cm} \times 35 \mathrm{~cm})$ of DEAE-Sephadex A-50 previously equilibrated with $50 \mathrm{~mm}-\mathrm{Tris} / \mathrm{HCl}$ buffer, $\mathrm{pH} 7.8$. After application of the enzyme the column was washed with equilibration buffer until the absorbance at $280 \mathrm{~nm}$ was essentially zero. Elution of the enzyme was performed with a $500 \mathrm{ml}$ linear gradient of $\mathrm{KCl}(0-250 \mathrm{mM})$ in the equilibration buffer. The flow rate was $15 \mathrm{ml} / \mathrm{h}$, and $10 \mathrm{ml}$ fractions were collected. Fractions were assayed for dihydropteridine reductase activity, and the absorbance at $280 \mathrm{~nm}$ was monitored. The reductase was eluted between
320 and $390 \mathrm{ml}(150 \mathrm{~mm}-\mathrm{KCl})$, and the active fractions were pooled.

CM-Sephadex chromatography. The pooled active fractions were dialysed exhaustively against $50 \mathrm{mM}$-Tris/ $\mathrm{HCl}$ buffer, $\mathrm{pH} 7.4$, before application to a CM-Sephadex C-50 column $(2 \mathrm{~cm} \times 20 \mathrm{~cm})$ equilibrated with the same buffer. The column was washed with $200 \mathrm{ml}$ of the equilibration buffer, and the reductase was then eluted with a $300 \mathrm{ml}$ linear gradient of $\mathrm{KCl}(0-250 \mathrm{mM})$ in the equilibration buffer. The flow rate was $10 \mathrm{ml} / \mathrm{h}, 10 \mathrm{ml}$ fractions being collected. Dihydropteridine reductase was eluted as a symmetrical peak of enzyme activity and absorbance at $280 \mathrm{~nm}$ in the $150 \mathrm{mM}-\mathrm{KCl}$ region of the gradient. The active fractions were combined, dialysed against $50 \mathrm{mM}$-Tris/ $\mathrm{HCl}$ buffer, $\mathrm{pH} 7.8$, and concentrated to $4-5 \mathrm{ml}$ by ultrafiltration (Sartorius collodion membrane with $50 \mathrm{~mm}$-Tris/ $\mathrm{HCl}$ buffer, pH 7.8).

\section{Electrophoretic methods}

Analytical discontinuous polyacrylamide-gel electrophoresis was performed at $\mathrm{pH} 9.4$ as described by Ornstein (1964) and Davis (1964) and at pH4.0 as described by Parish \& Marchalonis (1970). Sodium dodecyl sulphate/polyacrylamidegel electrophoresis was performed in accordance with the procedures described by Weber \& Osborn (1969). Cross-linking studies of the reductase with dimethyl suberimidate (Aldrich) were performed as described by Davies \& Stark (1970).

Testing for anomalous behaviour in these gel systems was performed by measuring the electrophoretic mobility of dihydropteridine reductase and standard proteins, at a series of different gel concentrations [see Hedrick \& Smith (1968) and Chrambach \& Rodbard (1971) for strategy of the method]. The results were analysed in a manner first proposed by Ferguson (1964), by plotting the logarithm of relative mobility $\left(R_{F}\right)$ against acrylamide gel concentration (Ferguson plot). Anomalous behaviour is indicated for proteins with an extrapolation point different from that of the standards on the Ferguson plot [as observed for the reductase in native disc electrophoresis (Fig. 4)].

Gradient gel (Gradipore) electrophoresis was performed as previously described (Cotton \& Jennings, 1978), and in a second buffer with a pH 9.6 electrophoresis buffer $(11.2 \mathrm{~g}$ of Tris, $0.96 \mathrm{~g}$ of EDTA and $0.36 \mathrm{~g}$ of boric acid/litre) and extended electrophoresis $\left(6000 \mathrm{~V}\right.$-h; $150 \mathrm{~V}$ for $40 \mathrm{~h}$ at $\left.4^{\circ} \mathrm{C}\right)$.

High-molecular-weight and low-molecular-weight calibration-kit protein standards (Pharmacia) were used in the above electrophoresis experiments.

Protein was stained with Coomassie Brilliant Blue $\mathrm{G} 250(0.04 \%)$ in $3.5 \%(\mathrm{v} / \mathrm{v}) \mathrm{HClO}_{4}$ and destained in $7 \%(v / v)$ acetic acid. Staining for enzyme activity 
was as previously described (Cotton \& Jennings, 1978).

\section{Analytical ultracentrifugation}

Sedimentation-equilibrium analysis was performed in a Beckman model $\mathrm{E}$ analytical ultracentrifuge equipped with the interference optical system. The molecular weight of the reductase $(0.25 \mathrm{mg} / \mathrm{ml}$ in $50 \mathrm{~mm}$-Tris/ $\mathrm{HCl}$ buffer, $\mathrm{pH} 7.5)$ was measured by the meniscus-depletion method of Yphantis (1964). The column height was $3 \mathrm{~mm}$ and the speed was $24000 \mathrm{rev} . / \mathrm{min}$.

\section{Gel filtration}

This was performed on a Sephadex G-100 column $(2 \mathrm{~cm} \times 74 \mathrm{~cm})$ with $50 \mathrm{~mm}$-Tris $/ \mathrm{HCl}$ buffer, $\mathrm{pH} 7.8$, as eluting buffer. The void volume $\left(V_{0}\right)$ was determined with Blue Dextran and the total volume $\left(V_{\mathrm{t}}\right)$ with tritiated water. The column was calibrated with the following proteins (Stokes radii in brackets); bovine serum albumin $[3.62 \mathrm{~nm}(36.2 \AA)]$, ovalbumin $[2.73 \mathrm{~nm}(27.3 \AA)]$, chymotrypsinogen $[2.09 \mathrm{~nm}$ $(20.9 \AA)]$, ribonuclease $[1.92 \mathrm{~nm}(19.2 \AA)]$ and cytochrome $c[1.64 \mathrm{~nm}(16.4 \AA)]$. The molecular weight of dihydropteridine reductase was calculated by the method of Andrews (1964). The Stokes radius of the enzyme was determined as described by Ackers (1964), and this was used to calculate the diffusion coefficient $\left(D_{20, \mathrm{w}}\right)$ as outlined by Svedberg \& Pedersen (1940).

\section{Amino acid analysis}

Samples $(50-100 \mu \mathrm{g})$ of native and $S$-carboxymethylated (Crestfield et al., 1963) preparations of the pure reductase were hydrolysed in $6 \mathrm{M}-\mathrm{HCl} / 1 \%$ 2-mercaptoethanol in evacuated tubes at $110^{\circ} \mathrm{C}$ for 24,48 and $72 \mathrm{~h}$. Amino acid analysis of the hydrolysates was performed on a Beckman 120C analyser. Tryptophan was determined by spectrophotometric (Edelhoch, 1967) and fluorimetric (Pajot, 1976) procedures.

\section{Two-dimensional polyacrylamide-gel electro- phoresis}

This was performed essentially as described by O'Farrell (1975). First-dimension isoelectric-focusing disc gels $(0.2 \mathrm{~cm} \times 12 \mathrm{~cm})$ of $5 \%$ polyacrylamide containing 2\% (w/v) Ampholines, $\mathrm{pH} 3.5-10$ (LKB Produkter, Bromma, Sweden), and $9.5 \mathrm{M}$-urea (AristaR grade) were run at room temperature for $16-18 \mathrm{~h}$ at a constant voltage of $400 \mathrm{~V}$. The second dimension used a $0.08 \mathrm{~cm} \times 9 \mathrm{~cm}$ resolving gel of $9 \%$ polyacrylamide and a $4.8 \mathrm{~cm}$ stacking gel of $4.5 \%$ polyacrylamide. First-dimension and second-dimension gels were fixed in $3.5 \% \mathrm{HClO}_{4}$ overnight before the staining for protein as described above.

Measurement of isoelectric points was based on the method of Righetti \& Drysdale (1974). Electro- focusing was performed in $6 \%$ polyacrylamide gels containing $10 \%(\mathrm{v} / \mathrm{v})$ glycerol and $2 \%(\mathrm{w} / \mathrm{v})$ ampholyte [pH 3.5-10 (LKB) or pH 6.5-9 (Pharmacia)]. After electrophoresis (at $400 \mathrm{~V}$ for $16 \mathrm{~h}$ at room temperature), the gels were sliced into $0.2 \mathrm{~cm}$ sections and extracted in $0.5 \mathrm{ml}$ of distilled water for $3 \mathrm{~h}$. The $\mathrm{pH}$ and enzyme activity of each extract were measured.

\section{Results}

\section{Isolation of dihydropteridine reductase from human} liver

The procedure employed in the isolation of dihydropteridine reductase from human liver involved (1) affinity chromatography on 1,2-naphthoquinone-AH-Sepharose, and ion-exchange chromatography on (2) DEAE-Sephadex and (3) CMSephadex.

The purification achieved in the affinity-chromatographic step was improved from 300 -fold (Cotton \& Jennings, 1978) to 700 -fold, through a modification of the buffers used in washing and eluting the reductase from the adsorbent (Fig. 1). A recovery of over $80 \%$ was obtained, and the enzyme showed a specific activity of 285 units $/ \mathrm{mg}$ of protein.

The enzyme was further purified by chromatography on DEAE-Sephadex and CM-Sephadex columns, where it was eluted as a single symmetrical peak of protein and activity at the $0.15 \mathrm{M}$ $\mathrm{KCl}$ region of the salt gradient employed (results not shown). The specific activity of the final product varied from one preparation to another, but was usually between 380 and 450 units/mg (six experiments). The purification procedure (summarized in Table 1) typically yields $4-5 \mathrm{mg}$ of 1000 -foldpurified dihydropteridine reductase from $300-400 \mathrm{~g}$ of liver tissue. Purified enzyme has been stored frozen at $-20^{\circ} \mathrm{C}$ for up to 2 years without loss of biological activity.

\section{Purity of enzyme}

Polyacrylamide-gel disc electrophoresis of the purified liver dihydropteridine reductase revealed the presence of only one protein band (Fig. 2a). Staining of a duplicate gel for enzyme activity gave a single band in a position corresponding to that of the protein band (Fig. 2b). On two-dimensional gel electrophoresis, which separates proteins according to their isoelectric point (pI) and subunit molecular weight, the purified enzyme preparation revealed a single spot (Fig. 2c). In one electrophoretic system (non-equilibrium pH-gradient electrophoresis; O'Farrell et al., 1977) the enzyme was resolved into two bands, the nature of which is discussed in the following paper (Firgaira et al., 1981).

Unless otherwise specified, the purified enzyme 


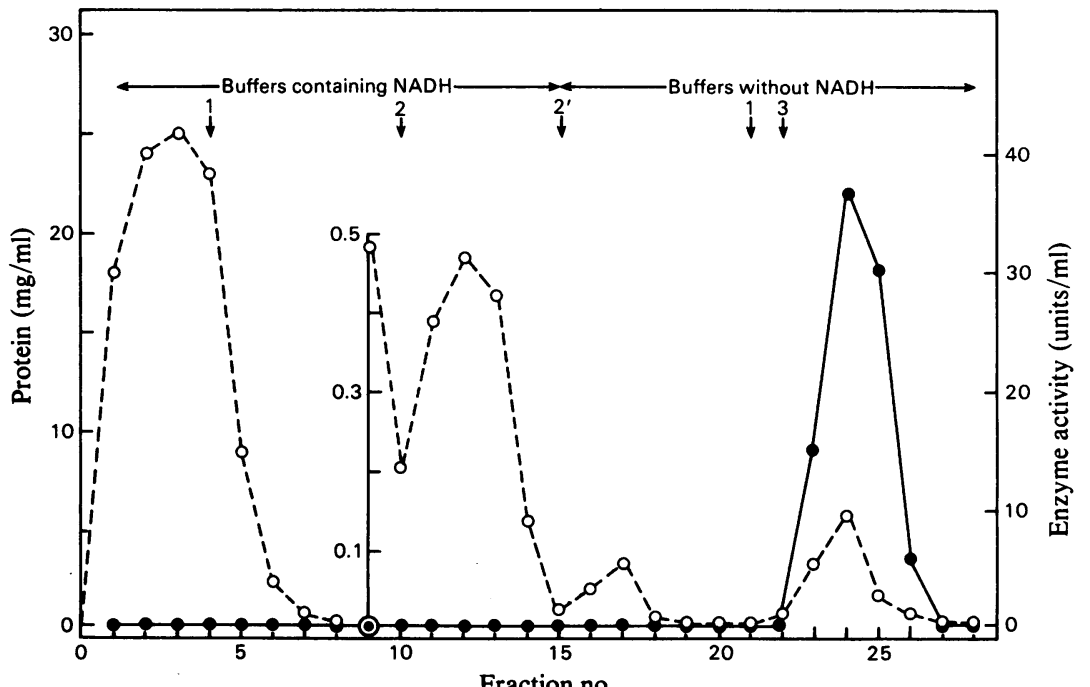

Fig. 1. Affinity chromatography of human liver dihydropteridine reductase on 1,2-naphthoquinone-AH-Sepharose After the application of liver (particle-free) extract, the column was washed successively with buffer 1 (pH 7.6) containing NADH (arrow 1), buffer 2 ( $\mathrm{pH} 10.9$ ) containing NADH (arrow 2) and buffer 2 without NADH (arrow $2^{\prime}$ ). Buffer 1 was then applied to the column until the eluate was neutral before elution of the reductase by buffer 3 (arrow 3), which contains $2 \mathrm{~mm}$-dithiothreitol. Fractions $(1-5,150 \mathrm{ml} ; 6-28,50 \mathrm{ml}$ ) were assayed for protein $(O)$ and dihydropteridine reductase activity $(O)$.
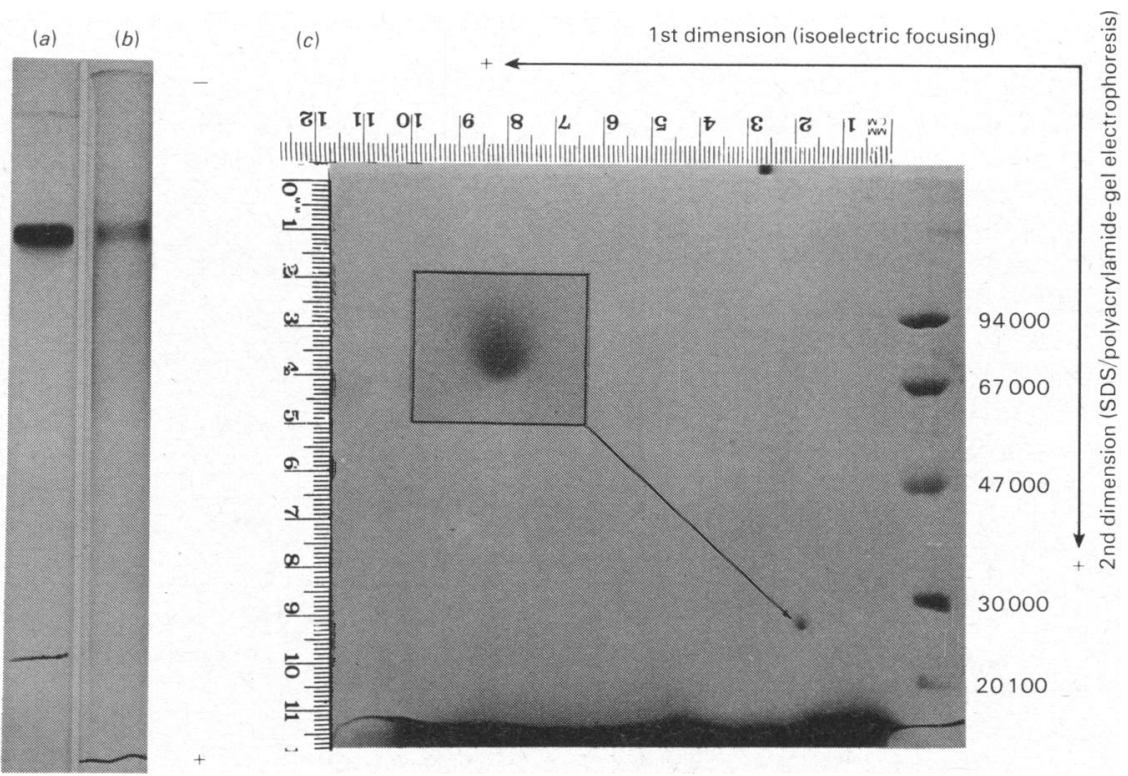

Fig. 2. Electrophoretic analysis of purified human liver dihydropteridine reductase

Disc electrophoresis at pH 9.4 of reductase $(a)(25 \mu \mathrm{g})$ stained for protein and $(b)(0.2 \mu \mathrm{g})$ stained for enzyme activity. (c) Two-dimensional polyacrylamide-gel electrophoresis of reductase $(10 \mu \mathrm{g})$ : isoelectric-focusing gel in first dimension and sodium dodecyl sulphate (SDS)/polyacrylamide (9\%) slab gel in the second dimension. Insert shows a close-up of the dihydropteridine reductase spot. 
Table 1. Isolation of dihydropteridine reductase from human liver For experimental details see the text.

$\begin{array}{lcccccc} & \begin{array}{c}\text { Volume } \\ (\mathrm{ml})\end{array} & \begin{array}{c}\text { Total protein } \\ (\mathrm{mg})\end{array} & \begin{array}{c}\text { Total } \\ \text { Penzyme activity } \\ \text { (units) }\end{array} & \begin{array}{c}\text { Yield } \\ (\%)\end{array} & \begin{array}{c}\text { Specific activity } \\ \text { (units/mg) }\end{array} & \begin{array}{c}\text { Purification } \\ \text { (fold) }\end{array} \\ \text { Crude extract } & 600 & 16094 & 6562 & 100 & 0.408 & 1 \\ \text { (1) Affinity chromatography } & 200 & 18.9 & 5380 & 82 & 285 & 699 \\ \text { (2) DEAE-Sephadex } & 72 & 10.2 & 3805 & 58 & 372 & 920 \\ \text { (3) CM-Sephadex } & 38 & 4.1 & 1732 & 26 & 422 & 1035\end{array}$

preparation was used for the following characterization studies.

\section{Determinations of the molecular weight of the native enzyme}

The molecular weight of native dihydropteridine reductase was determined by a number of procedures.

(1) Sedimentation-equilibrium analysis. This gave a linear plot of logarithm of the equilibrium protein concentration versus the square of radial distance from the centre of the rotor (results not shown), and indicates the absence of detectable contaminating protein material. From the slope of this plot and taking a partial specific volume for the enzyme of $0.736 \mathrm{ml} / \mathrm{g}$ [estimated from the amino acid composition (Table 2) by the procedure of Schachman (1957)], a molecular weight of 50000 was obtained for the enzyme.

(2) Gel-filtration chromatography. The molecular weight and the Stokes radius of the enzyme were determined by gel filtration on Sephadex G-100. A plot of $\log$ (molecular weight) of the standard proteins versus the partition coefficient $\left(K_{\mathrm{D}}\right)$ for each of the standards showed a linear correlation (results not shown). The molecular weight of the purified reductase was calculated from its observed $K_{\mathrm{D}}$ and a value of $47500 \pm 3000$ (six determinations) was obtained. The reductase activity from crude liver extract was found to be eluted from the column with the same elution volume $\left(V_{\mathrm{e}}\right)$ as the purified enzyme. A Stokes radius of $3.00 \mathrm{~nm}(30.0 \AA)$ was obtained by analysis of these data (Ackers, 1964). The diffusion coefficient $\left(D_{20, w}\right)$ was calculated to be $7.2 \times$ $10^{-7} \mathrm{~cm}^{2} / \mathrm{s}$ from the Stokes radius (Svedberg \& Pedersen, 1940).

(3) Molecular-weight analysis on gradient polyacrylamide gels. Our first experiments showed that the purified dihydropteridine reductase migrated to an apparent molecular weight of 150000 (i.e. slightly larger than lactate dehydrogenase) on analysis by gradient $(2.5-27 \%)$ polyacrylamide-gel electrophoresis (Fig. 3a). This finding is very different from the molecular-weight estimates obtained by the sedimentation-equilibrium and gel-filtration studies reported above, and suggests that the reductase may
Table 2. Amino acid composition of dihydropteridine reductase from various species

The numbers of residues were calculated on the basis of a subunit molecular weight of 25000 for human dihydropteridine reductase. The values given by (1) Craine et al. (1972), based on 21000, (2) Cheema et al. (1973) and (3) Korri et al. (1977), based on 26000, and (4) Hasegawa (1977), based on 25000, have been adjusted where necessary to a subunit molecular weight of 25000 for comparative purposes.

Residues per subunit (mol.wt. 25000)

\begin{tabular}{lcrrrr} 
Residue & $\begin{array}{c}\text { Human liver } \\
\text { (present work) }\end{array}$ & $\overbrace{(1)}$ & $(2)$ & $\overbrace{(3)}$ & $(4)$ \\
Asp & 16 & 18 & 19 & 17 & 15 \\
Thr & 17 & 15 & 18 & 15 & 18 \\
Ser & 18 & 21 & 20 & 18 & 22 \\
Glu & 22 & 26 & 26 & 23 & 21 \\
Pro & 9 & 10 & 9 & 10 & 9 \\
Gly & 26 & 26 & 24 & 20 & 22 \\
Ala & 31 & 30 & 32 & 26 & 32 \\
Sl-Cm-Cys & 3 & 1 & - & - & - \\
Val & 17 & 17 & 17 & 16 & 17 \\
Met & 4 & 4 & 5 & 5 & 5 \\
Ile & 8 & 6 & 7 & 7 & 6 \\
Leu & 21 & 20 & 25 & 21 & 22 \\
Tyr & 3 & 2 & 3 & 3 & 2 \\
Phe & 7 & 6 & 7 & 6 & 6 \\
His & 5 & 5 & 5 & 5 & 4 \\
Lys & 14 & 15 & 14 & 14 & 14 \\
Arg & 9 & 8 & 10 & 8 & 9 \\
Trp & 5 & 2 & 9 & 3 & 8 \\
$\frac{1}{2}$ Cys & - & - & 3 & 9 & 1 \\
Cys & - & 1 & - & - & - \\
& & & & & \\
\hline
\end{tabular}

be migrating in an anomalous manner in the gradient gel system.

Anomalous behaviour of dihydropteridine reductase on polyacrylamide gels

A good test for anomalous behaviour of proteins in polyacrylamide gels is the determination of the electrophoretic mobility of the protein of interest at a series of different polyacrylamide-gel concentrations (Chrambach \& Rodbard, 1971). As shown in 

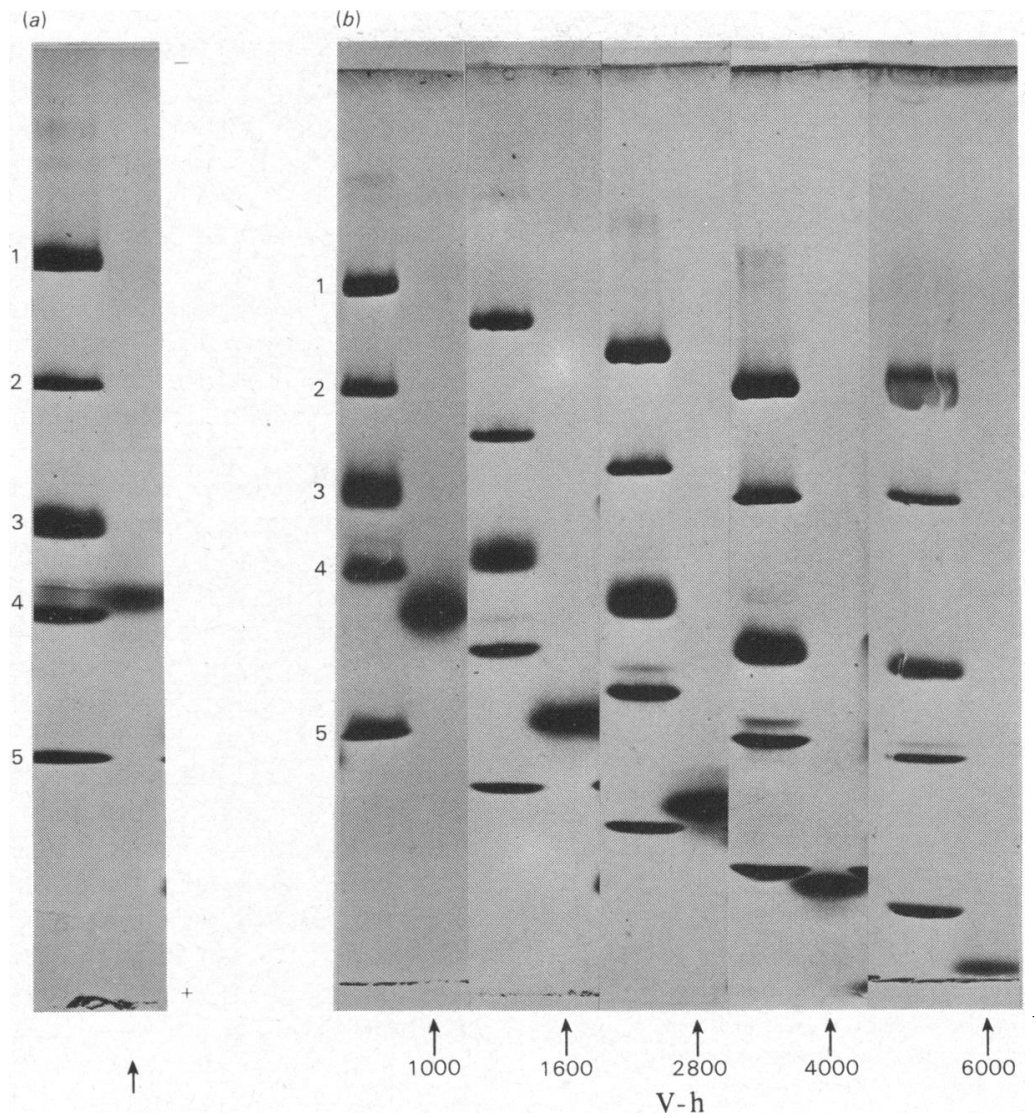

Fig. 3. Gradient polyacrylamide-gel electrophoresis of dihydropteridine reductase

(a) Electrophoresis at $\mathrm{pH} 8.7$ at $4^{\circ} \mathrm{C}$ for $1200 \mathrm{~V}-\mathrm{h}$; (b) electrophoresis at $\mathrm{pH} 9.6$ for increasing V-h periods. The dihydropteridine reductase track is marked by arrow and compared with protein standards (molecular weights in parentheses): 1, thyroglobulin (669000); 2, ferritin (440000); 3, catalase (232000); 4, lactate dehydrogenase (140000); 5, albumin (67000).

Fig. 4, dihydropteridine reductase shows a markedly different extrapolation point from that of the standard proteins in the resultant Ferguson plot. This indicates that caution should be used when comparing this protein to others in polyacrylamide-gel systems. At low polyacrylamide concentrations (approaching zero) there is very little retardation of protein migration by the sieving effect of the gel matrix, and protein migration is largely dependent on the net charge of the protein. As shown in Fig. 4, the reductase showed a lower mobility than many proteins of larger size at low polyacrylamide concentration. At higher polyacrylamide concentrations, where a size-sieving effect becomes more important, the reductase begins to approach the migration expected by its size. The results indicate a low net charge/size ratio for human dihydropteridine reductase, and are consistent with the relatively high isoelectric point ( $\mathrm{pI}$
$7.0 \pm 0.1)$ found for this enzyme. These characteristics suggest that in the electrophoretic conditions used prevously ( $\mathrm{pH} 8.7$ for $1200 \mathrm{~V}$-h) in gradient gel electrophoresis the enzyme bore a low relative charge and may not have reached its migration limit, leading to an erroneous estimate of its native molecular weight (Fig. 3a; Cotton \& Jennings, 1978). Molecular-weight determination by polyacrylamide gradient gels are only accurate if the migration rates of unknown and standard proteins approach zero and depend on the free mobility of the proteins at the selected electrophoresis $\mathrm{pH}$ and the period of electrophoresis.

At higher electrophoretic buffer $\mathrm{pH}$ values the relative net charge/size ratio of the reductase begins to resemble more closely that of the standard proteins used in calibration of the gel. As presented in Fig. 3(b), electrophoresis at $\mathrm{pH} 9.6$ for increasing periods showed that human dihydropteridine reduc- 


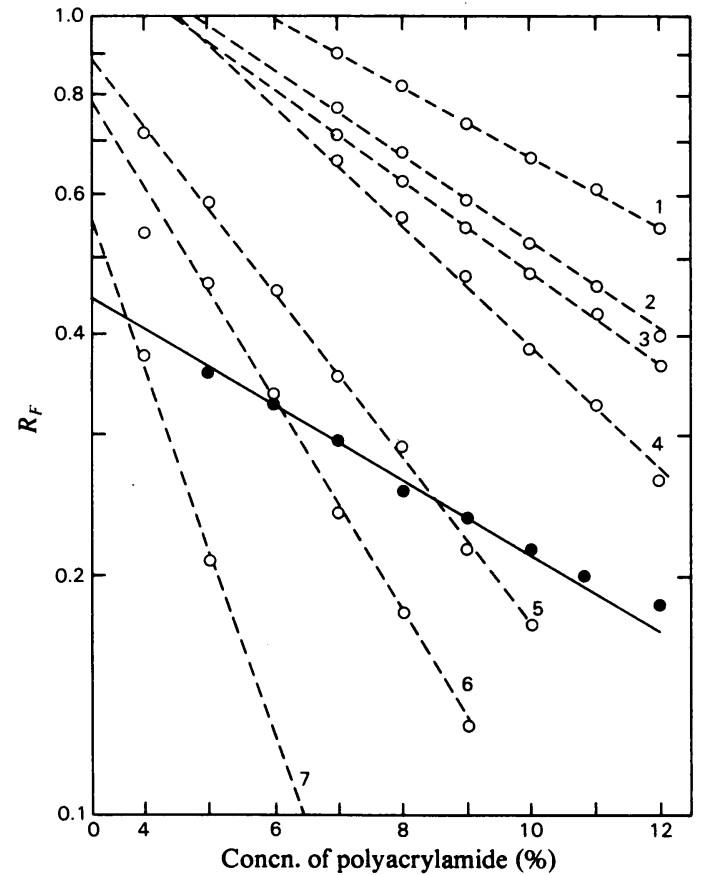

Fig. 4. Ferguson plot of dihydropteridine reductase migration on disc gel electrophoresis

Electrophoresis was performed at $\mathrm{pH} 9.4$ at $22^{\circ} \mathrm{C}$ in $0.5 \mathrm{~cm} \times 10 \mathrm{~cm}$ gels; protein migration is expressed relative to Bromophenol Blue migration $\left(R_{F}\right)$. Dihydropteridine reductase $(\bullet)$ migration is compared with that of protein standards (molecular weights in parentheses): 1, $\alpha$-lactalbumin (14400); 2 , carbonic anhydrase $(30000) ; 3$, ovalbumin (47000); 4, albumin (67000); 5, lactate dehydrogenase $(140000) ; 6$, catalase $(232000)$; 7 , thyroglobulin $(669000)$.

tase reaches its migration limit much more slowly than do the standard proteins, and begins to approach zero mobility only after $6000 \mathrm{~V}-\mathrm{h}$. At this stage calculation from the straight-line calibration curve obtained from a plot of $\log$ (molecular weight) against $\boldsymbol{R}_{\boldsymbol{F}}$ for the standard proteins (Figure not shown) indicated an apparent molecular weight of 54000 for the reductase.

A molecular weight of 50000 (average from molecular-weight studies) was used with the Stokes radius and partial specific volume to compute a frictional ratio $\left(f / f_{0}\right)$ of 1.23 for the enzyme by the method of Siegel \& Monty (1966).

\section{Subunit molecular weight}

Analysis of the purified enzyme preparation by sodium dodecyl sulphate/polyacrylamide-gel electrophoresis revealed one protein band with an apparent molecular weight of 26000 (Fig. 5). This value was confirmed by a Ferguson plot, which showed a linear relationship of $\log R_{F}$ of dihydropteridine reductase versus polyacrylamide concentration with the same intercept $\left(R_{F} 1.5\right)$ as those for plots for standard proteins (Fig. $5 d$ ).

Dimethyl suberimidate, a protein-cross-linking reagent, was used in studying the subunit structure of the enzyme (Davies \& Stark, 1970). When the reductase was treated with increasing concentrations of the suberimidate and analysed by sodium dodecyl sulphate / polyacrylamide - gel electrophoresis, a second protein band emerged at 58000 mol.wt., with a concurrent decrease in the intensity of the monomer band at 26000 mol.wt. (Figs. 5a-5c). The Ferguson plot of the cross-linked dimer ( $\square$ in Fig. $5 d$ ) shows the same intercept but a higher retardation coefficient than the monomer $(0$ in Fig. 5d), indicating a difference in molecular weight and not in charge between the two.

Assay for reductase activity before and after treatment with suberimidate $(4 \mathrm{mg} / \mathrm{ml}$, which resulted in near complete formation of the cross-linked dimer) indicated no significant alteration of enzyme activity. Gel filtration of the cross-linked material on Sephadex G-100 gave one symmetrical peak of enzyme activity, eluted at the same elution volume $\left(V_{\mathrm{e}}\right)$ as untreated enzyme, indicating a molecular weight of 47500 for the cross-linked dimer.

To test whether or not the two subunits were identical, polyacrylamide-gel electrophoresis was performed on the enzyme at $\mathrm{pH} 9.4$ and $\mathrm{pH} 4.0$ in $7.5 \%$ gels (as described in the Materials and methods section). Reductase samples $(10 \mu \mathrm{g})$ were treated separately with (i) $9 \mathrm{M}$-urea, (ii) $9 \mathrm{M}$-urea and $0.2 \%$ 2-mercaptoethanol and (iii) $9 \mathrm{M}$-urea, $0.2 \%$ 2-mercaptoethanol and $1 \mathrm{~mm}$-iodoacetamide. Electrophoresis of the treated samples in both the pH 9.4 and pH4.0 systems showed only one protein band on the gels. This indicates that the two subunits have similar electrophoretic mobilities, and, since they also have similar molecular weights (see above), the two subunits are presumably identical. This contention is also supported by the single spot observed in two-dimensional electrophoresis (Fig. $2 c$ ).

\section{Amino acid composition}

Amino acid analysis of two different preparations of purified human liver dihydropteridine reductase gave essentially the same results. These are presented in Table 2 and are compared with the known amino acid compositions of sheep and bovine liver dihydropteridine reductases.

\section{Subunit-NADH interaction}

Webber \& Whiteley (1978) showed that the addition of NADH to rat liver dihydropteridine 

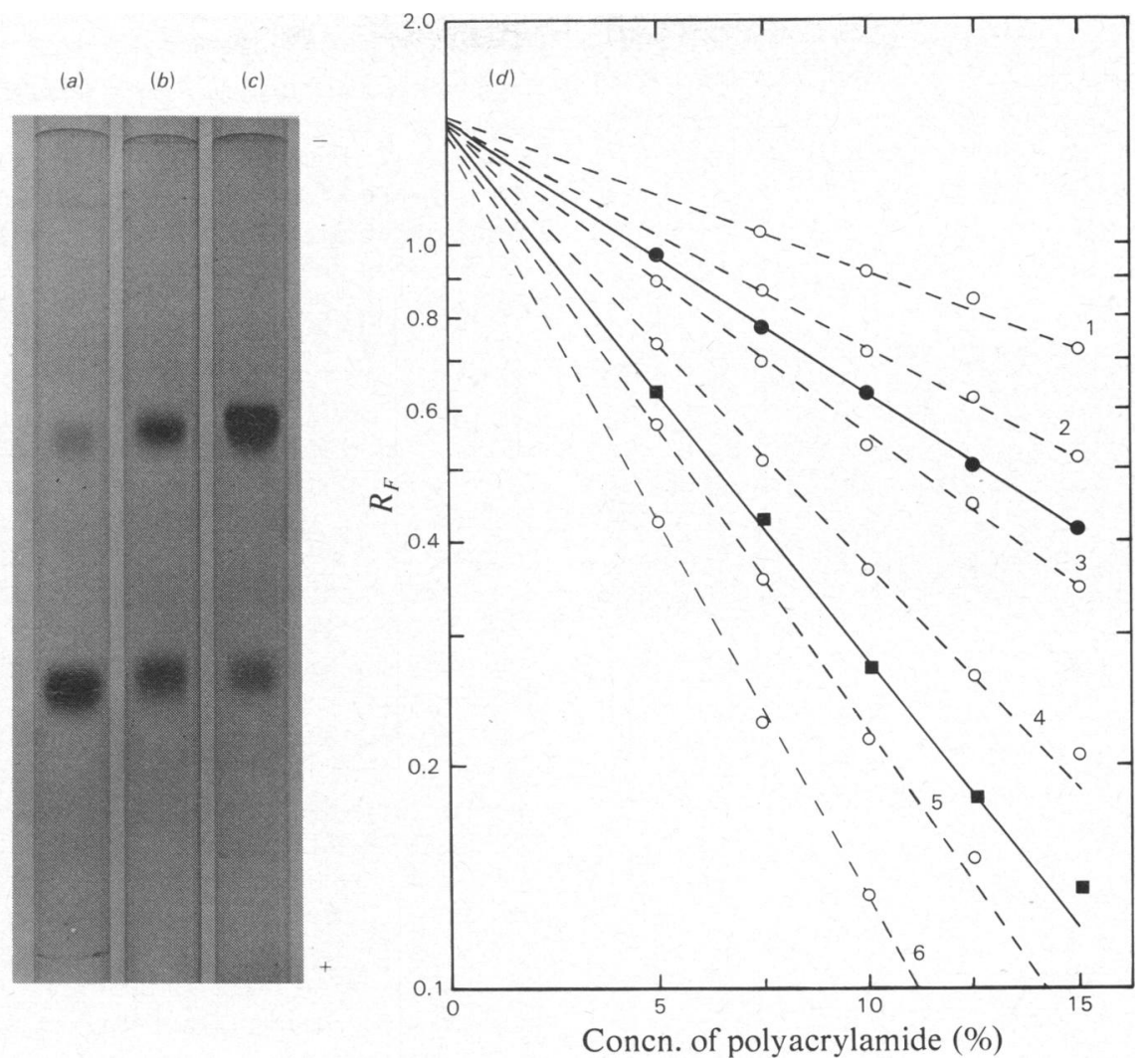

Fig. 5. Sodium dodecyl sulphate/ polyacrylamide-gel electrophoresis of dihydropteridine reductase Electrophoresis was performed at room temperature in $0.5 \mathrm{~cm} \times 10 \mathrm{~cm}$ gels; protein migration is expressed relative to Bromophenol Blue migration $\left(R_{F}\right)$. Gels $(a)-(c)$, purified enzyme $(15 \mu \mathrm{g})$ treated with dimethyl suberimidate at $0.02 \mathrm{mg} / \mathrm{ml}, 0.2 \mathrm{mg} / \mathrm{ml}$ and $2 \mathrm{mg} / \mathrm{ml}$ respectively. (d) Ferguson plots of reductase (O) and dimethyl suberimidate-treated enzyme $(\square)$ migration, compared with protein standards (subunit molecular weights in parentheses): 1, $\alpha$-lactalbumin (14400); 2, trypsin inhibitor (20100); 3, carbonic anhydrase (30000); 4, ovalbumin (47000); 5, albumin (67000); 6, phosphorylase $b(94000)$.

reductase followed by analysis on polyacrylamide gels under non-denaturating conditions revealed two bands, the enzyme and a faster-migrating band of enzyme-NADH complex.

Addition of NADH to the human liver enzyme produced a faster-migrating band of reductase, as indicated by protein (Figs. $6 a-6 c$ ) or enzymeactivity staining. To determine the nature of the observed heterogeneity in the presence of NADH, the mobilities of the two different dihydropteridine reductase bands were recorded as Ferguson plots. The faster-migrating band (enzyme-NADH complex) gave a line parallel to that observed for reductase alone (Fig. 4), indicating that the separation between these bands is caused by a difference in charge, not of molecular weight. As shown in Fig. 6, the intensity of the reductase-NADH band increased with the amount of NADH added. The conversion of enzyme into enzyme-NADH com- plex appeared to be nearly complete in the presence of 2 equiv. or more of NADH (Fig. 6c). A trace amount of the uncomplexed enzyme was still found with greater amounts (2-50 equiv.) of NADH.

These results suggest that each molecule of the human enzyme binds two molecules of NADH, which agrees with the findings made by Hasegawa (1977) for the bovine enzyme. No complexes with altered mobility could be detected when the reductase was incubated with up to a 100 -fold molar excess of NADPH, NAD ${ }^{+}$or 2-amino-4-hydroxy6,7-dimethyl-5,6,7,8-tetrahydropteridine.

\section{Isoelectric point}

The purified human liver dihydropteridine reductase was subjected to isoelectric focusing in a non-denaturing system (Righetti \& Drysdale, 1974). Enzyme activity could be extracted from the gels at a position corresponding to the single band of 
stained protein in duplicate gels. Use of broad-range ampholytes (pH3.5-10) indicated one peak of enzyme activity corresponding to pI $7.0 \pm 0.1$ (six determinations). A similar result was obtained with narrow-range ampholytes (pH 6.5-9.0).
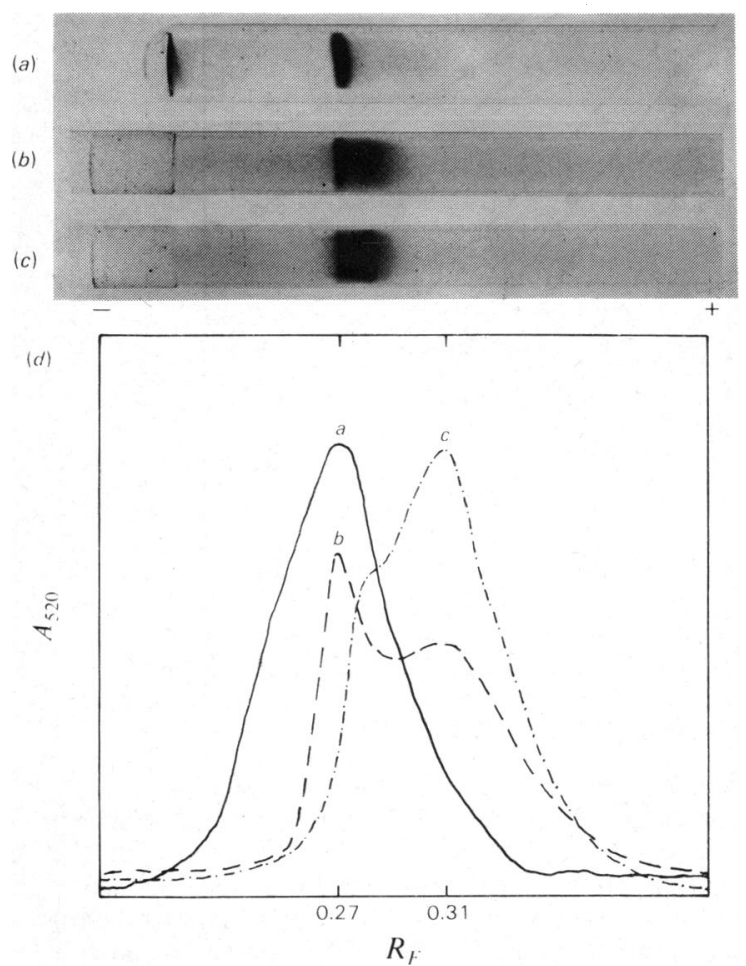

Fig. 6. Binding of NADH to dihydropteridine reductase Samples of purified dihydropteridine reductase $(10 \mu \mathrm{g}, 0.2 \mathrm{nmol})$ were incubated with various amounts of NADH $(0.05-10 \mathrm{nmol})$ for $15 \mathrm{~min}$ at room temperature. These were analysed by disc polyacrylamide-gel electrophoresis at $\mathrm{pH} 9.4$ with $7.5 \%$ polyacrylamide gels. Gel $(a)$, reductase $(0.2 \mathrm{nmol})$; gel $(b)$, reductase $(0.2 \mathrm{nmol})$ with NADH $(0.2 \mathrm{nmol})$; gel $(c)$, reductase $(0.2 \mathrm{nmol})$ with NADH $(0.4 \mathrm{nmol})$. (d) shows densitometric tracings obtained when gels $(a)-(c)$ were scanned at $520 \mathrm{~nm}$ (relative scale).

\section{Catalytic and kinetic properties}

Optimum $\mathrm{pH}$ and substrate specificity. Measurement of dihydropteridine reductase activity at various $\mathrm{pH}$ values (Tris/ $\mathrm{HCl}$ buffers, $\mathrm{pH} 5.8-9.8$ ) in the presence of NADH or NADPH as the electron donor showed optimal activity at $\mathrm{pH} 7.2$ for both nucleotides. The buffers used were adjusted with $\mathrm{HCl}$ to a desired $\mathrm{pH}$ at $20^{\circ} \mathrm{C}$. In determining the actual assay $\mathrm{pH}$ at $37^{\circ} \mathrm{C}$, a correction factor of $0.025 /{ }^{\circ} \mathrm{C}$ was applied (temperature coefficient of Tris buffer used). A buffer adjusted to $\mathrm{pH} 7.65$ at $20^{\circ} \mathrm{C}$ is used in the standard assay. NADH was 20 -fold more effective as an electron donor than NADPH for the reaction with the synthetic cofactor 2-amino-4-hydroxy-6,7-dimethyl-5,6,7,8tetrahydropteridine. A similar $\mathrm{pH}$-activity profile was observed with tetrahydrobiopterin, but NADH was only 2.5 -fold more effective than NADPH in this reaction.

Temperature. The assay reaction mixture (see the Materials and methods section) containing equal amounts of the purified reductase $(50 \mathrm{ng})$ was incubated at different temperatures $\left(15-45^{\circ} \mathrm{C}\right)$ by means of a water-jacketed cell holder and thermostatically controlled circulating water bath. After 10 min incubation the reaction rate was determined by addition of the pterin to the mixture; this showed an increase in activity with temperatue, reaching a maximum at $37^{\circ} \mathrm{C}$ (results not shown).

These experiments are in agreement with our previous observations of dihydropteridine reductase activity in human cultured cells and liver extracts (Firgaira et al., 1979).

Kinetic constants. The effect of varying the concentration of substrates on the measured enzymic activity was determined. This showed typical hyperbolic curves for plots of velocity versus substrate concentration. The $K_{\mathrm{m}}$ and $V_{\text {max. }}$ values for tetrahydrobiopterin, the synthetic cofactor, NADH and NADPH were determined from Lineweaver-Burk plots and are presented in Table 3 . The lower $K_{\mathrm{m}}$ and $V_{\text {max. }}$ values observed for NADH show that this is a more effective substrate than NADPH in the reaction. This is in agreement with observations with other mammalian reductases (Nielsen et al., 1969; Craine et al., 1972; Cheema

Table 3. Kinetic data for human liver dihydropteridine reductase

Values were measured at $37^{\circ} \mathrm{C}$ at $\mathrm{pH} 7.2$ (for further experimental details see the text).

\begin{tabular}{|c|c|c|c|}
\hline Substrate & $K_{\mathrm{m}}(\mu \mathrm{M})$ & $\frac{V_{\max .}}{(\mu \mathrm{mol} / \mathrm{min} \text { per } \mathrm{mg})}$ & Concn. of second substrate \\
\hline $\begin{array}{l}\text { NADH } \\
\text { NADPH }\end{array}$ & 29 & 468 & $\begin{array}{l}\text { Synthetic cofactor* }(75 \mu \mathrm{M}) \\
\text { Synthetic cofactor* }(75 \mu \mathrm{M})\end{array}$ \\
\hline $\begin{array}{l}\text { NADPH } \\
\text { Tetrahydrobi }\end{array}$ & 770 & $\begin{array}{l}316 \\
239\end{array}$ & $\begin{array}{l}\text { Synthetic cofactor* }(75 \mu \mathrm{M}) \\
\text { NADH }(100 \mu \mathrm{M})\end{array}$ \\
\hline Synthetic cofactor* & 36 & 612 & NADH $(100 \mu \mathrm{M})$ \\
\hline
\end{tabular}

* 2-Amino-4-hydroxy-6,7-dimethyl-5,6,7,8-tetrahydropteridine. 
et al., 1973). The enzyme showed a higher affinity (lower $K_{\mathrm{m}}$ ) for the natural cofactor tetrahydrobiopterin than for the synthetic cofactor; however, higher enzyme activity was observed with the latter, as indicated by the higher $V_{\text {max }}$ observed with this substrate (Table 3). This has also been observed for the sheep liver enzyme (Craine et al., 1972). On the basis of the observed $V_{\text {max. }}$ (Table 3 ) and a molecular weight of 50000 , human liver dihydropteridine reductase shows a turnover number (molecules of product synthesized $/ \mathrm{min}$ by each molecule of enzyme) of $1.20 \times 10^{4}$ and $3.06 \times 10^{4}$ for tetrahydrobiopterin and synthetic cofactor respectively.

Substrate inhibition by pterin was previously observed for the crude extract enzyme at concentrations of the synthetic cofactor above $100 \mu \mathrm{M}$ (Firgaira et al., 1979). This was not apparent with the pure enzyme. However, use of cofactor concentrations above approx. $100 \mu \mathrm{M}$, though not affecting the initial velocity (over $1 \mathrm{~min}$ ), caused a marked decrease in the reaction after this period. Higher concentrations $(>100 \mu \mathrm{M})$ of substrates (synthetic cofactor and/or NADH) in our assay system produced disturbance of the spectrophotometric signal and recording. Substrate inhibition was observed with tetrahydrobiopterin concentrations above $50 \mu \mathrm{M}$.

The effects of various compounds on dihydropteridine reductase activity were examined. The results are presented in parentheses after the specified compound and indicate the concentration of the compound required to produce the stated percentage inhibition of reductase activity. Among the thiol-blocking inhibitors tested $\mathrm{HgCl}_{2}(0.1 \mu \mathrm{M}$; $60 \%)$, p-chloromercuribenzoate $(0.01 \mathrm{mM} ; 70 \%)$ and 5,5'-dithiobis-(2-nitrobenzoic acid) $(0.1 \mathrm{~mm} ; 60 \%)$ markedly inhibited the enzyme, whereas $N$-ethylmaleimide (1 $\mathrm{mM} ; 76 \%)$ and iodoacetamide $(10 \mathrm{mM}$; $70 \%)$ showed less effect. Use of these compounds at concentrations one order of magnitude higher than those shown above produced total inhibition of activity. Preincubation of the enzyme with $0.1 \mathrm{~mm}$ NADH provided complete protection from inhibition. We have found three $S$-carboxymethylcysteine residues per subunit (Table 2); the inhibition observed with the thiol-blocking reagents suggests that human dihydropteridine reductase activity is dependent on accessible thiol groups. These findings are in agreement with the observations made by Cheema et al. (1973) with the sheep liver enzyme and by Webber et al. (1978) with both sheep and rat liver reductases; however, Craine et al. (1972) could not detect inhibition of their sheep liver enzyme preparation by thiol-blocking reagents, and Aksnes et al. (1979) have indicated that cystine is not part of the active site of the bovine liver enzyme. The arginine-specific reagent butane-2,3-dione (Woodroofe \& Butterworth, 1979) at $10 \mathrm{~mm}$ produced $90 \%$ inhibition of activity, and complete protection from inactivation was observed by preincubation with NADH. Arginine has been implicated in the nucleotide-binding sites of many dehydrogenases (Lange et al., 1974; Bleile et al., 1975; Nagradova \& Asryants, 1975), and this may also be true for the reductase.

The effects of metal ions were also examined: $\mathrm{MgCl}_{2}(10 \mathrm{mM})$ and $\mathrm{MnCl}_{2}(10 \mathrm{~mm})$ had no effect on enzyme activity, but $\mathrm{CoCl}_{2}$ was observed to inhibit by $30 \%$ at $0.01 \mathrm{~mm}$ concentration. Williams et al. (1976) found a reverse pattern of inhibition of bacterial reductase, which was unaffected by $\mathrm{CoCl}_{2}$ but inhibited by $\mathrm{MgCl}_{2}, \mathrm{MnCl}_{2}$ and $\mathrm{CdCl}_{2}$. Metalion-chelating agents EDTA $(10 \mathrm{mM}), o$-phenanthroline ( $1 \mathrm{mM})$ and $2,2^{\prime}$-bipyridyl $(1 \mathrm{mM})$ had no inhibitory effect on enzyme activity, indicating that dihydropteridine reductase does not have a metal-ion requirement, as seen for some dehydrogenase enzymes.

\section{Discussion}

The three-step chromatographic procedure described achieves efficient purification of homogeneous dihydropteridine reductase, which constitutes approximately $0.1 \%$ of the total soluble protein from human liver.

The molecular properties of human liver dihydropteridine reductase are summarized in Table 4. It shows major similarities in molecular weight (Table 4), amino acid composition (Table 2), dimeric structure (Fig. 5) and substrate specificity (Table 3) to the reductase from sheep (Craine et al., 1972; Cheema et al., 1973), bovine (Hasegawa, 1977; Aksnes et al., 1979) and rat livers (Webber et al., 1978).

However, distinct differences exist between the various dihydropteridine reductases. We found pI 7.0 for human liver dihydropteridine reductase, whereas the enzyme from sheep and rat liver showed pI 5.4 and 6.35 respectively (Webber et al., 1978), and pI 5.7 has been shown for the bovine brain enzyme (Snady \& Musacchio, 1978) and liver enzyme (Aksnes et al., 1979). Differences have also been demonstrated in kinetic constants $\left(K_{\mathrm{m}}, K_{\mathrm{i}}\right)$ for the reductase from different species (Craine et al., 1972; Cheema et al., 1973; Webber et al., 1978; Firgaira et al., 1979).

Human dihydropteridine reductase forms an enzyme-NADH complex that is stable to gel electrophoresis (Fig. 6). Hasegawa (1977) has suggested that bovine liver dihydropteridine reductase binds two molecules of NADH per enzyme molecule, and Aksnes et al. (1979) have indicated that the binding site on each of the two subunits are identical with each other and do not interact. Webber \& Whiteley (1978) demonstrated that the 
Table 4. Molecular properties of human dihydropteridine reductase

Molecular weight

From sedimentation equilibrium $\quad 50000$

From gel filtration $\quad 47500$

From gradient polyacrylamide-gel electrophoresis $\quad 54000$

Subunit molecular weight

Sodium dodecyl sulphate/polyacrylamide-gel electrophoresis $\quad 26000$

Cross-linked dimer (dimethyl suberimidate) $\quad 58000$

Stokes radius

Diffusion coefficient

Frictional ratio

Partial specific volume

Isoelectric point

$K_{\mathrm{m}}\left(\mathrm{NADH}, 37^{\circ} \mathrm{C}, \mathrm{pH} 7.2\right)$

$K_{\mathrm{m}}\left(\mathrm{NADPH}, 37^{\circ} \mathrm{C}, \mathrm{pH} 7.2\right)$

$K_{\mathrm{m}}$ (synthetic cofactor, ${ }^{*} 37^{\circ} \mathrm{C}, \mathrm{pH} 7.2$ )

$3.0 \mathrm{~nm}(30 \AA)$

$7.2 \times 10^{-7} \mathrm{~cm}^{2} / \mathrm{s}$

1.23

$0.736 \mathrm{ml} / \mathrm{g}$

$7.0 \pm 1$

$29 \mu \mathrm{M}$

$770 \mu \mathrm{M}$

$K_{\mathrm{m}}$ (tetrahydrobiopterin, $37^{\circ} \mathrm{C}, \mathrm{pH} 7.2$ )

* 2-Amino-4-hydroxy-6,7-dimethyl-5,6,7,8-tetrahydropteridine.

rat liver reductase is capable of binding only one molecule of NADH per molecule of enzyme. Titration of the human enzyme with increasing concentrations of NADH suggests that it interacts with 2 equiv. of NADH (Fig. 6), but further studies are required to quantify this accurately.

Our sedimentation-equilibrium and gel-filtration studies indicated a native molecular weight of approx. 50000 for the purified human liver dihydropteridine reductase. Careful studies showed that the molecular weight of 100000 , reported by Cotton \& Jennings (1978) from studies with gradient polyacrylamide (Gradipore) gel, resulted from anomalous behaviour of the enzyme in this system. Use of the procedures outlined by Chrambach \& Rodbard (1971) showed (Fig. 4) that the reductase exhibits a low net charge/size ratio. This indicates that in gradient polyacrylamide-gel electrophoresis human dihydropteridine reductase migrates more slowly than do the standards used to calibrate the gel. Margolis \& Kenrick (1969), who developed this procedure, pointed out a similar anomalous behaviour for haemoglobin (mol.wt. 65000, pI 7.0), which migrated at an apparent higher molecular weight than transferrin (mol.wt. 90000). At higher electrophoretic buffer $\mathrm{pH}$ values the relative net charge/size ratio of the reductase would more closely resemble that of the standard proteins. By an increase of the buffer $\mathrm{pH}$ and allowing a longer period $(\mathrm{V}-\mathrm{h})$ for electrophoresis, dihydropteridine reductase was shown to migrate to its expected molecular weight in polyacrylamide gradient gels (Fig. 3). In contrast with the anomalous migration observed for the enzyme in non-denaturing polyacrylamide-gel electrophoresis, its migration was found to be normal when examined by sodium dodecyl sulphate / polyacrylamide - gel electro- phoresis (Fig. 5); this is consistent with a masking of protein charge brought about by this detergent.

In summary, characterization of human liver dihydropteridine reductase has shown basic similarities of size, subunit structure and amino acid composition to the enzyme from a variety of other species; however, differences in isoelectric points, kinetic constants, NADH-binding ratios and mobility in polyacrylamide-gel systems suggest that distinct variation in physical characteristics exists among the various mammalian dihydropteridine reductase enzymes.

The isolation and characterization of normal human dihydropteridine reductase will now permit analysis of mutant dihydropteridine reductase from patients with deficiency of this enzyme.

Dr. T. A. A. Dopeide and Dr. E. F. Woods (Division of Protein Chemistry, C.S.I.R.O.) are thanked respectively for amino acid analysis and ultracentrifuge studies. Dr. W. L. F. Armarego (Australian National University) is thanked for supplying tetrahydrobiopterin. F. A. F. was the recipient of a Commonwealth Postgraduate Research Award.

\section{References}

Ackers, G. K. (1964) Biochemistry 3, 723-730

Aksnes, A., Skotland, T., Flatmark, T. \& Ljones, T. (1979) Neurochem. Res. 4, 385-398

Andrews, P. (1964) Biochem. J. 91, 222-233

Bleile, D. M., Foster, M., Brady, J. W. \& Harrison, J. H. (1975) J. Biol. Chem. 250, 6222-6227

Chauvin, M. M., Korri, K. K., Tirpak, A., Simpson, R. C. \& Scrimgeour, K. G. (1979) Can. J. Biochem. 57, $178-187$

Cheema, S., Soldin, S. J., Knapp, A., Hofmann, T. \& Scrimgeour, K. G. (1973) Can. J. Biochem. 51, 1229-1239 
Chrambach, A. \& Rodbard, D. (1971) Science 172 , 440-451

Cotton, R. G. H. \& Jennings, I. (1978) Eur. J. Biochem. 83, 319-324

Craine, J. E., Hall, E. S. \& Kaufman, S. (1972) J. Biol. Chem. 247, 6082-6091

Crestfield, A. M., Moore, A. \& Stein, W. H. (1963) J. Biol. Chem. 238, 622-627

Danks, D. M., Bartholome, K., Clayton, B. E., Curtius, H., Grobe, H., Kaufman, S., Leeming, R., Pfleiderer, W., Rembold, H. \& Rey, F. (1978) J. Inherited Metab. Dis. 1, 49-54

Davies, G. E. \& Stark, G. R. (1970) Proc. Natl. Acad. Sci. U.S.A. 66, 651-656

Davis, B. J. (1964) Ann. N.Y. Acad. Sci. 121, 404-427

Edelhoch, H. (1967) Biochemistry 6, 1948-1954

Ferguson, K. A. (1964) Metab. Clin. Exp. 13, 985-1002

Firgaira, F. A., Cotton, R. G. H. \& Danks, D. M. (1979) Clin. Chim. Acta 95, 47-59

Firgaira, F. A., Choo, K. H., Cotton, R. G. H. \& Danks, D. M. (1981) Biochem. J. 197, 45-53

Hasegawa, H. (1977) J. Biochem. (Tokyo) 81, 169-177

Hedrick, J. L. \& Smith, A. J. (1968) Arch. Biochem. Biophys. 126, 155-164

Horecker, B. L. \& Kornberg, A. (1948) J. Biol. Chem. 175, 385-390

Kaufman, S. \& Fisher, D. B. (1974) in Molecular Mechanisms of Oxygen Activation (Hayaishi, O., ed.), pp. 285-369, Academic Press, New York

Korri, K. K., Chippel, D., Chauvin, M. M., Tirpak, A. \& Scrimgeour, K. G. (1977) Can. J. Biochem. 55, 1145-1152

Lange, L. G., Riordan, J. F. \& Vallee, B. L. (1974) Biochemistry 13, 4361-4370

Lineweaver, H. \& Burk, D. (1934) J. Am. Chem. Soc. 56, 658-666
Lowry, O. H., Rosebrough, N. J., Farr, A. L. \& Randall, R. J. (1951) J. Biol. Chem. 193, 265-275

Margolis, J. \& Kenrick, K. G. (1969) Nature (London) 221, 1056-1057

Nagradova, N. K. \& Asryants, R. A. (1975) Biochim. Biophys. Acta 386, 365-368

Nielsen, K. H., Simonsen, V. \& Lind, K. E. (1969) Eur.J. Biochem. 9, 497-502

O'Farrell, P. H. (1975) J. Biol. Chem. 250, 4007-4021

O'Farrell, P. Z., Goodman, H. M. \& O'Farrell, P. H. (1977) Cell 12, 1133-1142

Ornstein, L. (1964) Ann. N.Y. Acad. Sci. 121, 321-349

Pajot, P. (1976) Eur. J. Biochem. 63, 263-269

Parish, C. R. \& Marchalonis, J. J. (1970) Anal. Biochem. 34, 436-450

Righetti, P. G. \& Drysdale, J. W. (1974) J. Chromatog. 98, 271-321

Schachman, H. K. (1957) Methods Enzymol. 4, 32-103

Siegel, L. M. \& Monty, K. J. (1966) Biochim. Biophys. Acta 112, 346-362

Snady, H. \& Musacchio, J. M. (1978) Biochem. Pharmacol. 27, 1939-1945

Svedberg, T. \& Pederson, K. (1940) The Ultracentrifuge, pp. 34-51, Oxford University Press, Oxford

Webber, S. \& Whiteley, J. M. (1978) J. Biol. Chem. 253, 6724-6729

Webber, S., Deits, T. L., Snyder, W. R. \& Whiteley, J. M. (1978) Anal. Biochem. 84, 491-503

Weber, K. \& Osborn, M. (1969) J. Biol. Chem. 244, 4406-4412

Williams, C. D., Dickens, G., Letendre, C. H., Guroff, G., Haynes, C. \& Shiota, T. (1976) J. Bacteriol. 127, 1197-1207

Woodroofe, M. N. \& Butterworth, P. J. (1979) Biochem. J. 181, 137-142

Yphantis, D. A. (1964) Biochemistry 3, 297-317 